\title{
Dose-Dependent Associations between Wine Drinking and Breast Cancer Risk - Meta-Analysis Findings
}

\author{
Jia-Yan Chen ${ }^{1 \&}$, Hong-Cheng Zhu ${ }^{1 \&}$, Qing Guo ${ }^{2 \&}$, Zheng Shu ${ }^{3}$, Xu-Hui Bao ${ }^{4}$, \\ Feng Sun ${ }^{5}$, Qin Qin ${ }^{1}$, Xi Yang ${ }^{1}$, Chi Zhang ${ }^{1}$, Hong-Yan Cheng ${ }^{6}$, Xin-Chen Sun ${ }^{1 *}$
}

\begin{abstract}
Purpose: To investigate any potential association between wine and breast cancer risk. Materials and Methods: We quantitatively assessed associations by conducting a meta-analysis based on evidence from observational studies. In May 2014, we performed electronic searches in PubMed, EmBase and the Cochrane Library to identify studies examining the effect of wine drinking on breast cancer incidence. The relative risk $(\mathrm{RR})$ or odds ratio $(\mathrm{OR})$ were used to measure any such association. Results: The analysis was further stratified by confounding factors that could influence the results. A total of twenty-six studies (eight case-control and eighteen cohort studies) involving 21,149 cases were included in our meta-analysis. Our study demonstrated that wine drinking was associated with breast cancer risk. A $36 \%$ increase in breast cancer risk was observed across overall studies based on the highest versus lowest model, with a combined RR of 1.0059 (95\% CI 0.97-1.05) in dose-response analysis. However, $5 \mathrm{~g} / \mathrm{d}$ ethanol from wine seemed to have protective value from our non-linear model. Conclusions: Our findings indicate that wine drinking is associated with breast cancer risk in a dosedependent manner. High consumption of wine contributes to breast cancer risk with protection exerted by low doses. Further investigations are needed for clarification.
\end{abstract}

Keywords: Breast cancer - riskfactor - wine - alcohol - dose-dependent influence - meta-analysis

Asian Pac J Cancer Prev, 17 (3), 1221-1233

\section{Introduction}

Breast cancer is an important public health issue, as it is the leading malignancy with high incidence and mortality among women globally (Arveux and Bertaut, 2013). Several risk factors, such as first-degree family history, breast cancer susceptibility gene 1 (BRCA1) and BRCA2 mutations, were identified and related to breast cancer (Espie et al., 2013). Wine, as a special type of alcohol beverage, contains more than one chemoprotective chemical, including iso-flavone phytoestrogens, flavones, and procyanidin B dimmers (Eng et al., 2003; Key et al., 2006). In 2007, the International Agency for Research on Cancer (IARC) classified alcohol as carcinogenic to several human malignancies (Seitz and Stickel, 2007). Since then, the association between alcohol and breast cancer risk attracted much attention. Several epidemiological studies have demonstrated that alcohol consumption was associated with an increased risk of breast cancer (Smith-Warner et al., 1998; Corrao et al., 1999; Ellison et al., 2001; Singletary and Gapstur, 2001; Hamajima et al., 2002; Chen et al., 2011). However, results from studies seem controversial (Willett et al., 1997; Higgins et al., 2003; Bessaoud and Daures, 2008). Some issues about alcohol and breast cancer still remain complex and not well understood, such as the different effect of beverage choice (wine, liquor or beer). There was little evidence on whether different types of alcoholic beverage, including wine, liquor, and beer, play similar roles.

Meanwhile the dose-risk relation of wine intake with breast cancer hasn't yet been completely studied in detail. In particular, it is still not clearly established whether low dose wine consumption was associated with protective effect on breast cancer. It seems that more precise quantification and identification of a possible threshold for effect of wine are needed to be decided.

We herein performed a dose-response meta-analysis to investigate the potential association between wine and breast cancer risk.

\section{Materials and Methods}

Search strategy and selection criteria

Medline, Embase, and the Cochrane Library were

${ }^{1}$ Department of Radiation Oncology, The First Affiliated Hospital of Nanjing Medical University, ${ }^{6}$ Department of General Internal Medicine, The First Affiliated Hospital of Nanjing Medical University, Nanjing, ${ }^{2}$ Department of Oncology, Taizhou People's Hospital, Taizhou, Jiangsu, ${ }^{3}$ Department of Innovation and Translational Medicine, State Administration of Traditional Chinese Medicine of China, ${ }^{5}$ Department of Epidemiology and Biostatistics, School of Public Health, Peking University Health Science Center, Beijing, China, ${ }^{4}$ Department of Pathology, School of Medicine, Duke University, Durham, NC, USA *For correspondence: sunxinchen2012@163.com 
searched from inception to May 8th 2015 with the following subject heading terms and/or text words: "breast cancer", "breast neoplasm" in combination with "wine", "alcohol", "drinking", "beverage". In addition, a broader search on diet and breast cancer was also conducted. Further, the reference lists of retrieved articles and relevant review articles were scanned. No language restrictions were imposed.

According to "Food, nutrition, physical activity, and the prevention of cancer: a global perspective", wine was defined as alcoholic drinks produced from grapes and contain between around 9 to 15 per cent alcohol; The composition of wine depends on the grape varieties used, including red wine, white wine, sparking wine, et al (Wiseman, 2008). Studies were included if they (i) had a case-control or cohort design; (ii) evaluated the association between wine drinking and breast cancer risk; (iii) presented odds ratio (OR), relative risk (RR) estimates with $95 \%$ confidence interval (CI). If publications were duplicated or articles from the same study population, the publication with a larger scale was included. Nonpeer-reviewed articles, ecologic assessments, correlation studies, experimental animal studies and mechanistic studies were excluded. All the process was conducted by two independent investigators (Jiayan Chen and Hongcheng Zhu).

\section{Data extraction and quality assessment}

Two independent investigators (Jiayan Chen and Hongcheng Zhu) extracted the following data from each study that met the criteria for inclusion: first author, year of publication, geographic regions, journal, number of cases, cohort size, cohort name and duration of follow-up (cohort studies), number and type of control subjects (case-control studies), type of cancer, consumption categories, adjusted ORs, or RRs with 95\%CI, and adjusted variables. When several risk estimates were presented for pre- and postmenopause, year group, and et al. the detailed information was also extracted.

A 9-star system on the basis of the Newcastle-Ottawa Scale was used to assess the study quality from 3 broad perspectives. Considering that there is possibly a direct or indirect caloric intake with breast cancer risk, an energyadjusted residual or nutria-density model was added as an item for the scoring system (Willett et al., 1997). Hence, the full score was 10 stars, and a study with $\geq 7$ awarded stars was defined the high-quality study (Willett et al., 1997).

\section{Data synthesis and statistical analyses}

RRs with $95 \%$ CIs were calculated using randomeffects model. ORs were considered to be equivalent to RRs since breast cancer is a rare outcome. If association estimations were provided separately from subtypes or age group of cancer, combined RRs with $95 \%$ CIs were used in the overall analysis.

Statistical analyses based on comparison of the highest intake category with the lowest intake category (which included people do not drink) were conducted. Subgroup analyses were conducted by study quality, study design (cohort studies and case-control studies), control source (population-based and hospital-based), menopause, geographic region (Europe and North America), country (Italy, France, USA, and Canada) and study adjustments (family history, body mass index, total energy, other alcohol/beverage, smoking, menopause, hormone therapy, pregnancy, and education).

In addition, categorical dose-response regression analysis was utilized. The fixed-effects linear model was first used and non-linearity test was checked. Otherwise, Flexible nonlinear meta-regression models were used. The amount of wine consumption was converted into grams of ethanol per day using the following equivalencies: 1 drink $=12.5 \mathrm{~g}$, if not otherwise specified in the original report; 1 ounce $=28.35 \mathrm{~g}$. Midpoint of the range of categories reported in the original reports was assigned as levels of wine consumption, and for open-ended upper categories, as 1.2 times its lower bound. Wines are estimated as $12 \mathrm{v} / \mathrm{v}$ of ethanol approximately according to the majority products in the market.

Heterogeneity among studies were examined using the chi-square test, defining a significant heterogeneity as a $P$ value $<0.10$ and quantified the inconsistency using the I-squared statistic(Higgins et al., 2003). Publication bias was evaluated by generating funnel plots and the Egger's test (Egger et al., 1997).

\section{Results}

\section{Study characteristics}

26 eligible articles were identified from the database (Figure 1), including 8 cohort studies and 18 case-control studies (Table 1 and 2) (Webster et al., 1983; Le et al., 1984; Talamini et al., 1984; La Vecchia et al., 1985; Willett et al., 1987; Adami et al., 1988; Hiatt et al., 1988; Richardson et al., 1989; Toniolo et al., 1989; Rosenberg et al., 1990; Ferraroni et al., 1991; Martin-Moreno et al., 1993; Freudenheim et al., 1995; Levi et al., 1996; Viel et al., 1997; Ferraroni et al., 1998; Zhang et al., 1999; Horn-Ross et al., 2002; Lenz et al., 2002; Mattisson et al., 2004; Petri et al., 2004; Levi et al., 2005; Bissonauth et al., 2009; Dennis et al., 2010; Kabat et al., 2011; Link et al., 2013). Fourteen studies were conducted in Europe,

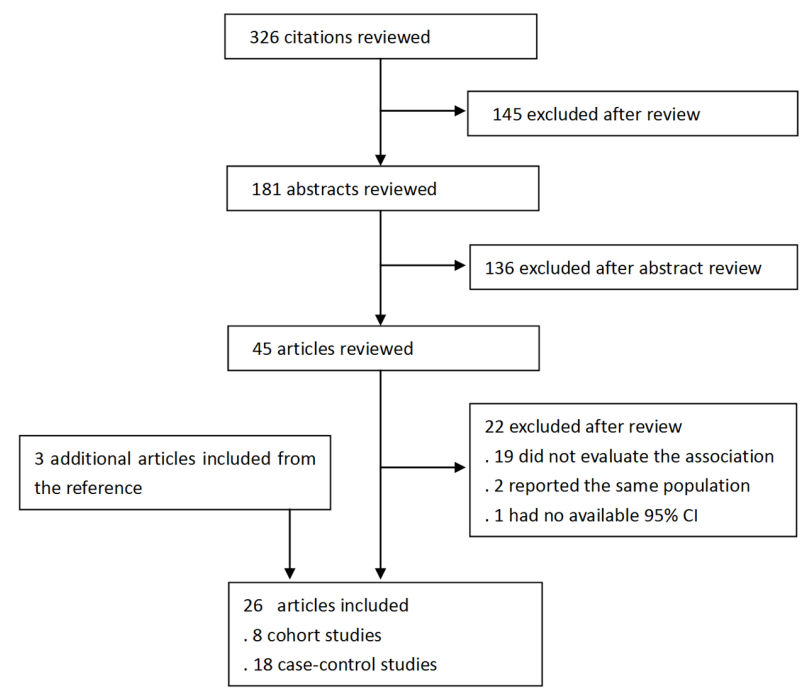

Figure 1. Reference Searched and Selection of Studies in the Meta-analysis 
eight in America, three in Canada and one across both continentals. A total of 1, 8106 breast cancer cases were included. Study-specific quality scores are summarized in Tables 3 and 4, which ranged from 4 to 10 stars with a median score of 8 stars. High-quality studies ( $\geq 7$ stars) included 10 case-control studies and all 8 cohort studies.

\section{Association between wine and breast cancer}

The summary RR was 1.36 (95\% CI: $1.20-1.54$, $P<0.001)$ across all the studies based on the highest versus lowest model (Figure 2), consistent with the results of cohort studies ( $\mathrm{RR}=1.25,95 \% \mathrm{CI}: 1.07-1.46, P=0.037)$, case-control studies $(\mathrm{RR}=1.44,95 \% \mathrm{CI}: 1.19-1.73$, $P<0.001)$, and high-quality (score $\geq 7)$ studies $(\mathrm{RR}=1.26$, 95\% CI: $1.12-1.43, P=0.002)$.

\section{Subgroup analysis}

The subgroup analysis on geographic area showed an RR of $1.66(95 \% \mathrm{CI}=1.35-2.05, P<0.001)$ in European studies, an RR of $1.18(95 \% \mathrm{CI}=1.09-1.27, P=0.58)$

Table 1. Characteristics of Prospective Cohort Studies of Wine Drinking and Breast Cancer Risk a

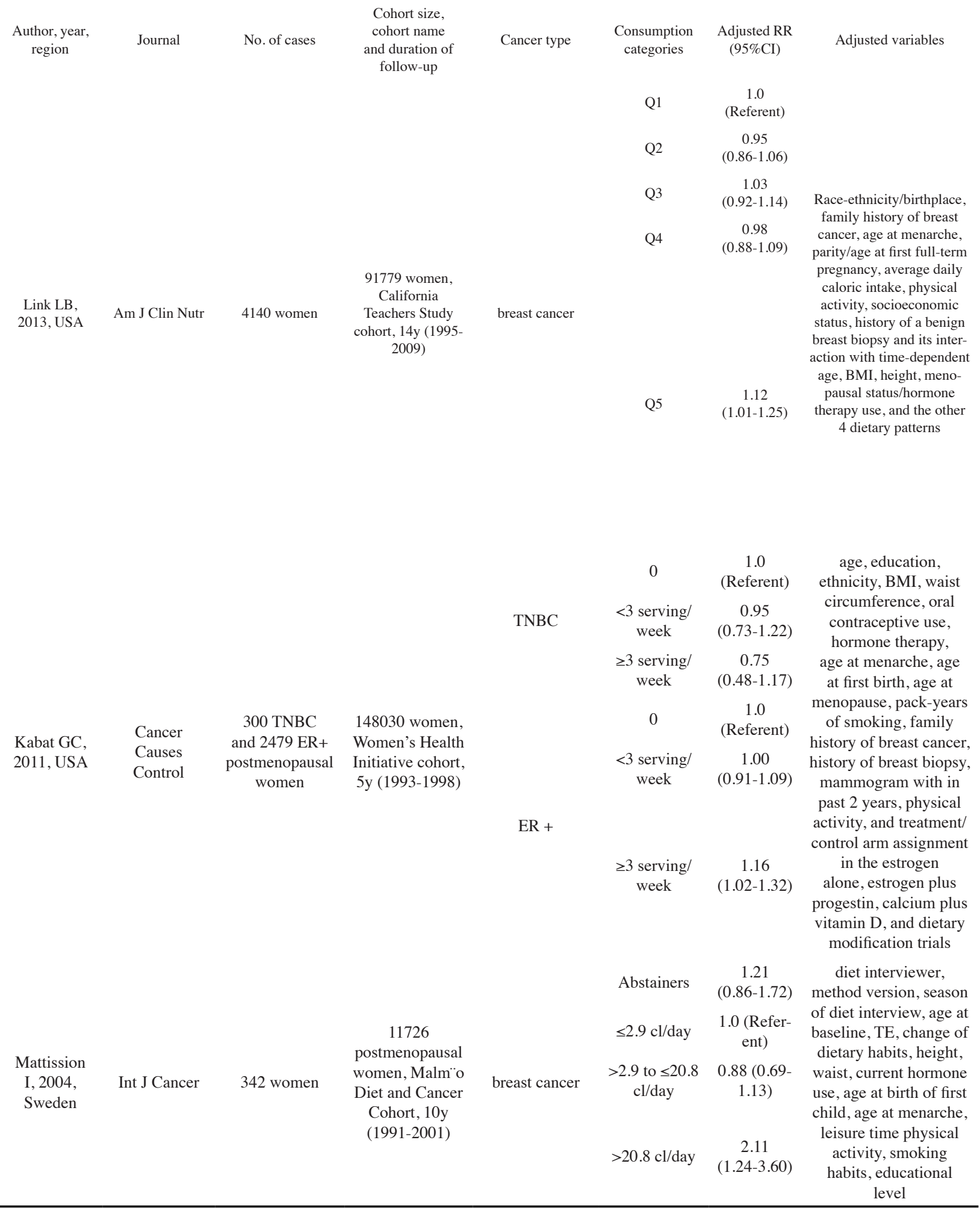




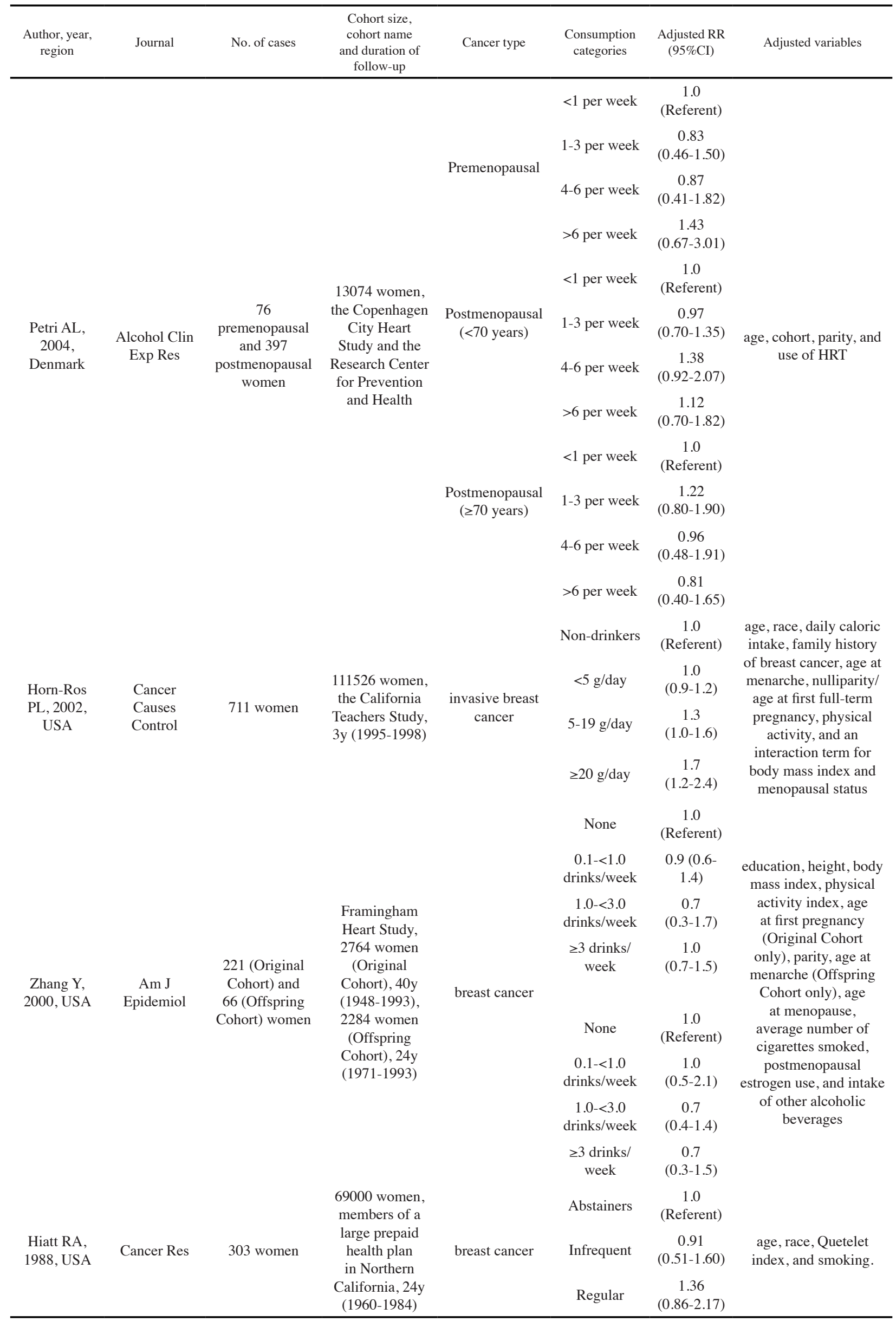


DOI:http://dx.doi.org/10.7314/APJCP.2016.17.3.1221

Dose-Dependent Association Between Wine Drinking and Breast Cancer Risk

Table 1. Characteristics of Prospective Cohort Studies of wine Drinking and Breast Cancer Risk ${ }^{\text {a }}$ (continued)

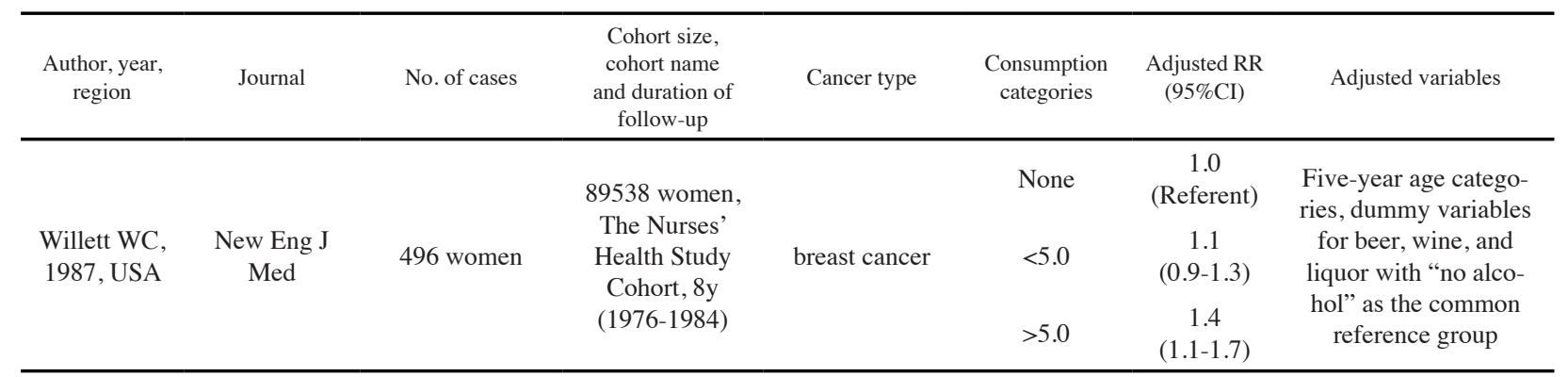

${ }^{\mathrm{a}} \mathrm{RR}=$ relative risk (rate ratio or hazard ratio); $\mathrm{CI}=$ confidence interval; $\mathrm{BMI}=$ body mass index; $\mathrm{TNBC}=$ triple-negative breast cancer; $\mathrm{ER}=$ estrogen receptor;

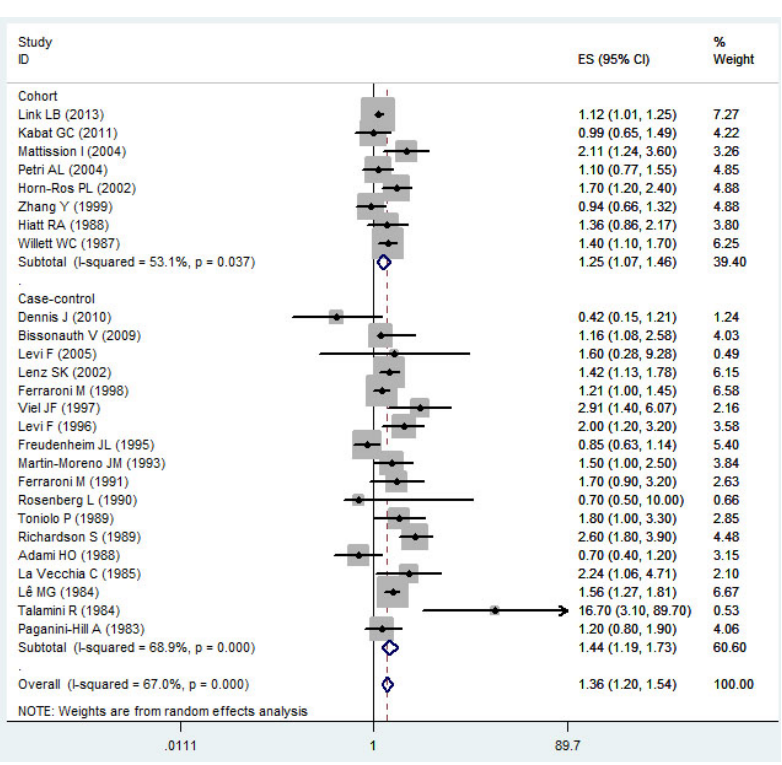

Figure 2. Estimates (95\% CIs) of Wine Drinking (Highest Versus Lowest Category) and Breast Cancer Risk

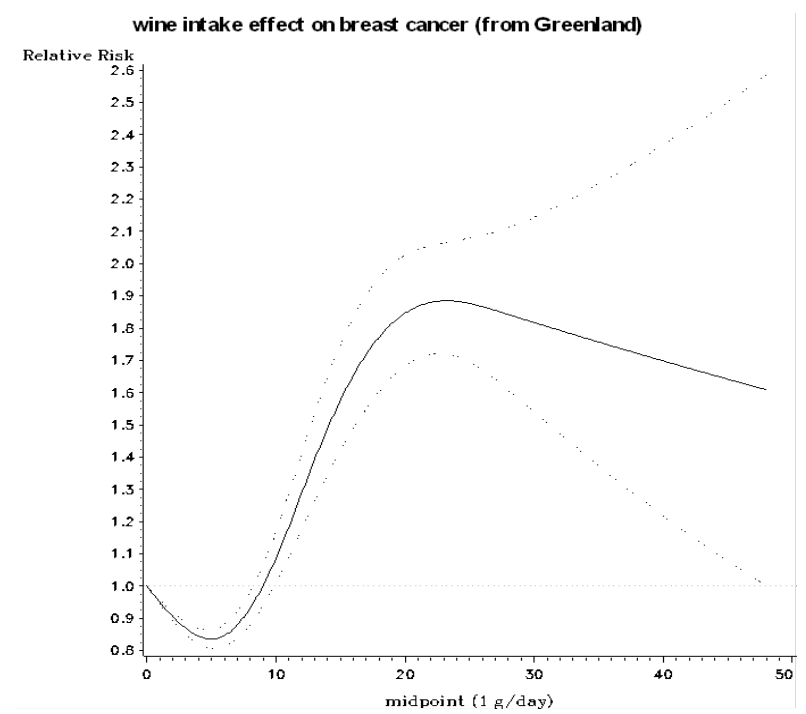

Figure 3. Ethanol Intake Effect on Breast Cancer

in North American (American and Canadian) studies. Notably, the RR was 2.12 in French studies $((95 \%$ CI $=1.37-3.27, P=0.024)$ and 1.89 in Italy studies $(95 \% \mathrm{CI}$ $=1.17-3.07, P=0.011$ ), respectively. Three studies reported data for premenopausal breast cancer patients, with a pooled RR of 1.79 (95\% $\mathrm{CI}=1.34-2.40, P=0.344)$, while

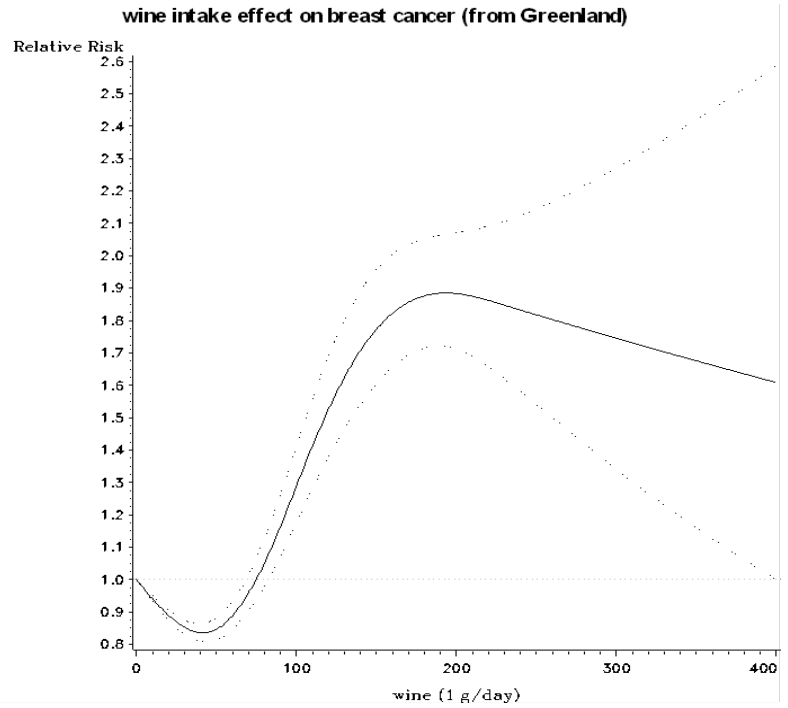

Figure 4. Wine Intake Effect on Breast Cancer

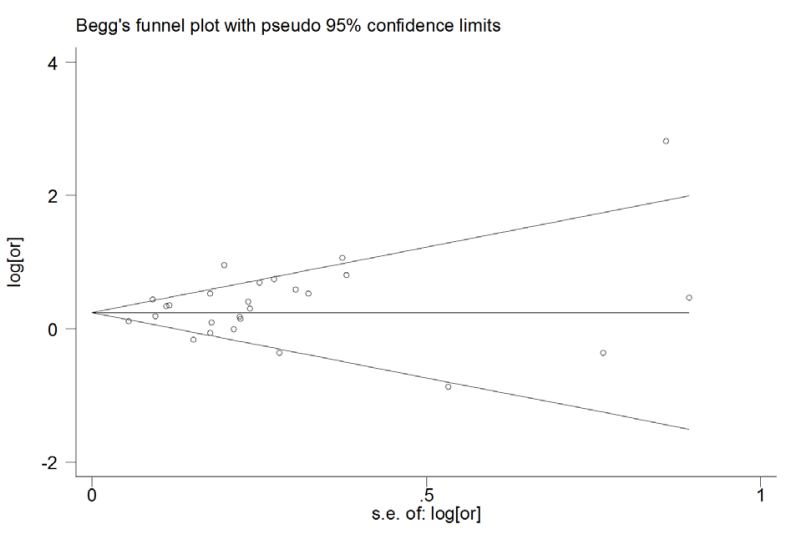

Figure 5. Beeg's Test of Studies for Wine Drinking and Breast Cancer Risk

5 studies had results for postmenopausal cases, with a RR of $1.20(95 \% \mathrm{CI}=0.94-1.53, P=0.027)$. When data were adjusted by some confounding factors (family history, body mass index, total energy, other alcohol beverage smoking, menopause, hormone therapy, pregnancy, education, physical activity), the association was still statistically significant (Table 5).

Dose-response analysis

Furthermore, dose-response meta-analyses were conducted. Most of the slope of each study was greater than 0 , indicating that more wine consumption might 


\section{Jiayan Chen et al}

lead to higher risk of breast cancer (Table 6). The fixedeffects model was first used. The heterogeneity between studies was detected. Therefore, a random-effect model was implemented next. Table 7 showed the combined RR was $1.0059(95 \% \mathrm{CI}=0.9670-1.0464, \mathrm{p}=0.6156)$ for overall meta-analysis, indicating a $0.59 \%$ increase in the risk of breast cancer for each increment of $1 \mathrm{~g}$ per day ethanol from wine under random effect model. The test of non-linearity was significant $(\chi 2=1763.9 P<0.0001)$, thus a non-linear dose-response model was performed. Figure 3 and 4 illustrated RR variation of breast cancer according to curvilinear thresholds of regular ethanol/ wine consumption. Wine was associated with breast cancer in a dose-dependent manner. The risk decreased when women who consumed below $10 \mathrm{~g}$ (ethanol) / 80g (wine) $[<1$ standard drink] per day. The risk declined to the bottom at the threshold of $5 \mathrm{~g} / \mathrm{d}$ of ethanol and $40 \mathrm{~g} / \mathrm{d}$ of wine, respectively.

\section{Publication bias}

Figure 5 shows the contour-enhanced funnel plot of studies on the association between wine and breast cancer

Table 2. Characteristics of Case-control Studies of Wine Drinking and Breast Cancer Risk ${ }^{\mathrm{a}}$

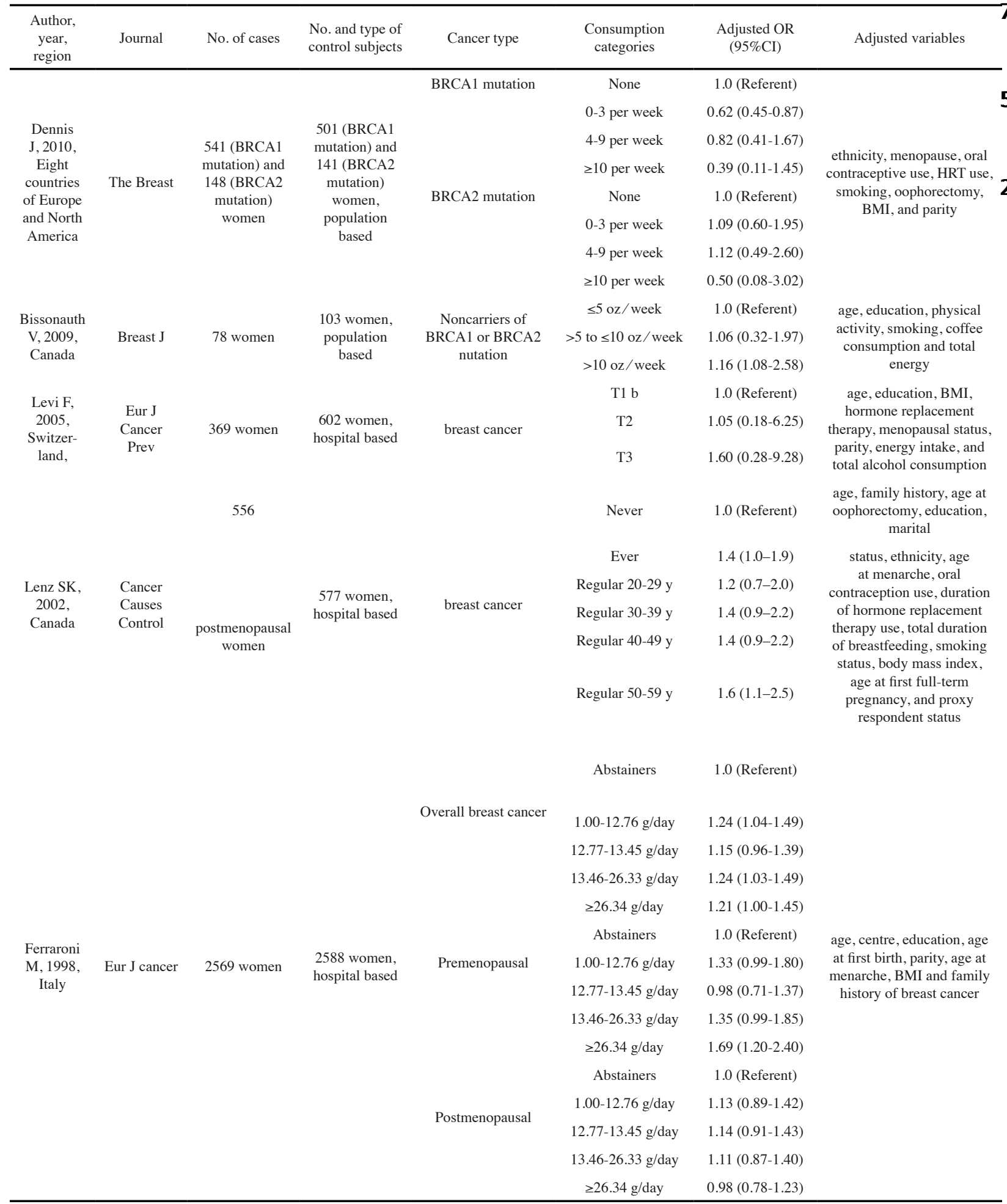


DOI:http://dx.doi.org/10.7314/APJCP.2016.17.3.1221

Dose-Dependent Association Between Wine Drinking and Breast Cancer Risk

Table 2. Characteristics of Case-control Studies of Wine Drinking and Breast Cancer Risk ${ }^{\text {a }}$ (continued)

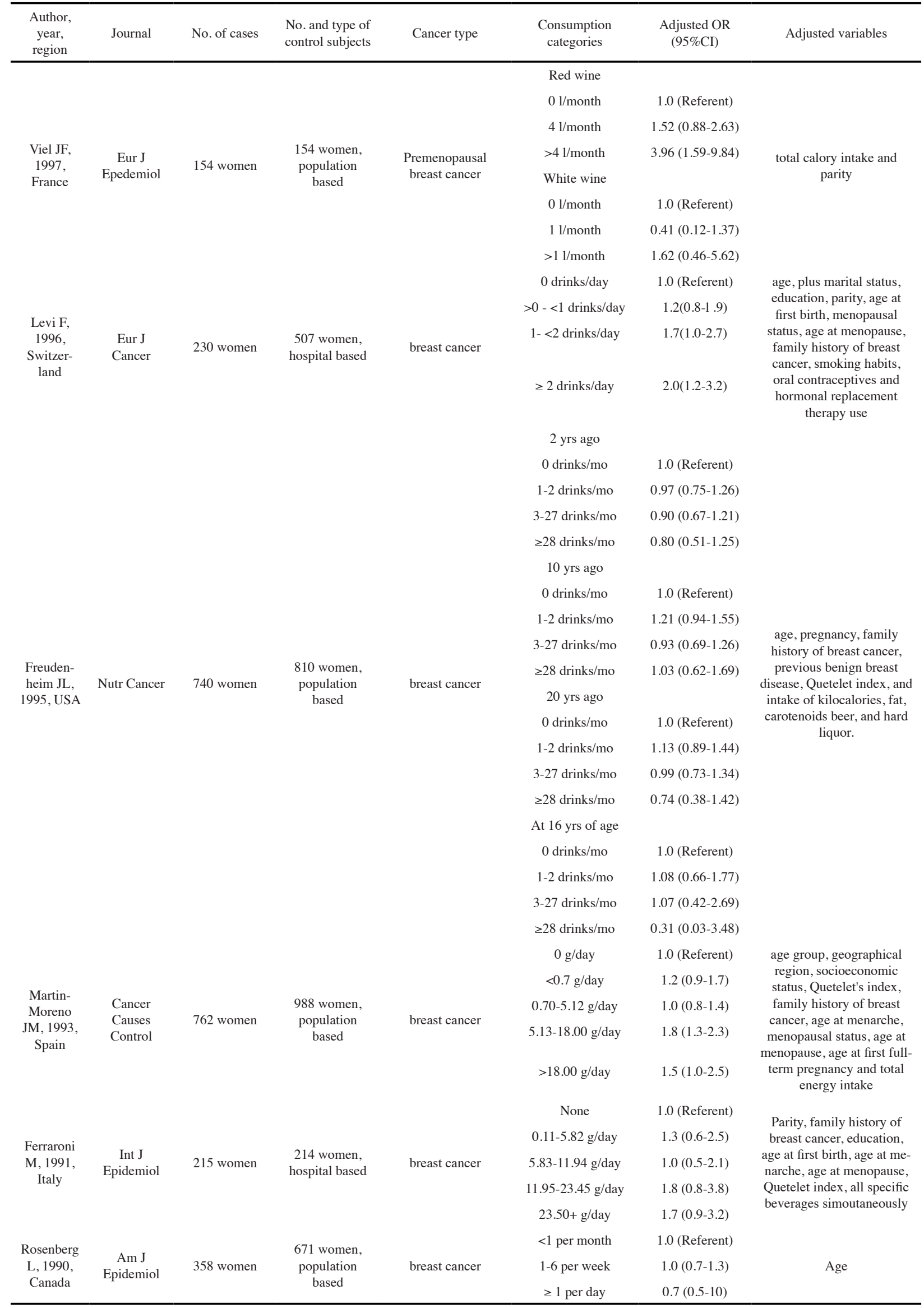

risk. The graph appears to be symmetrical, suggesting the absence of a publication bias. Likewise, we found no asymmetry according to the Egger's test $(P=0.151)$ and Begg's test $(P=0.243)$. 
Table 2. Characteristics of Case-control Studies of Wine Drinking and Breast Cancer Risk ${ }^{\text {a }}$ (continued)

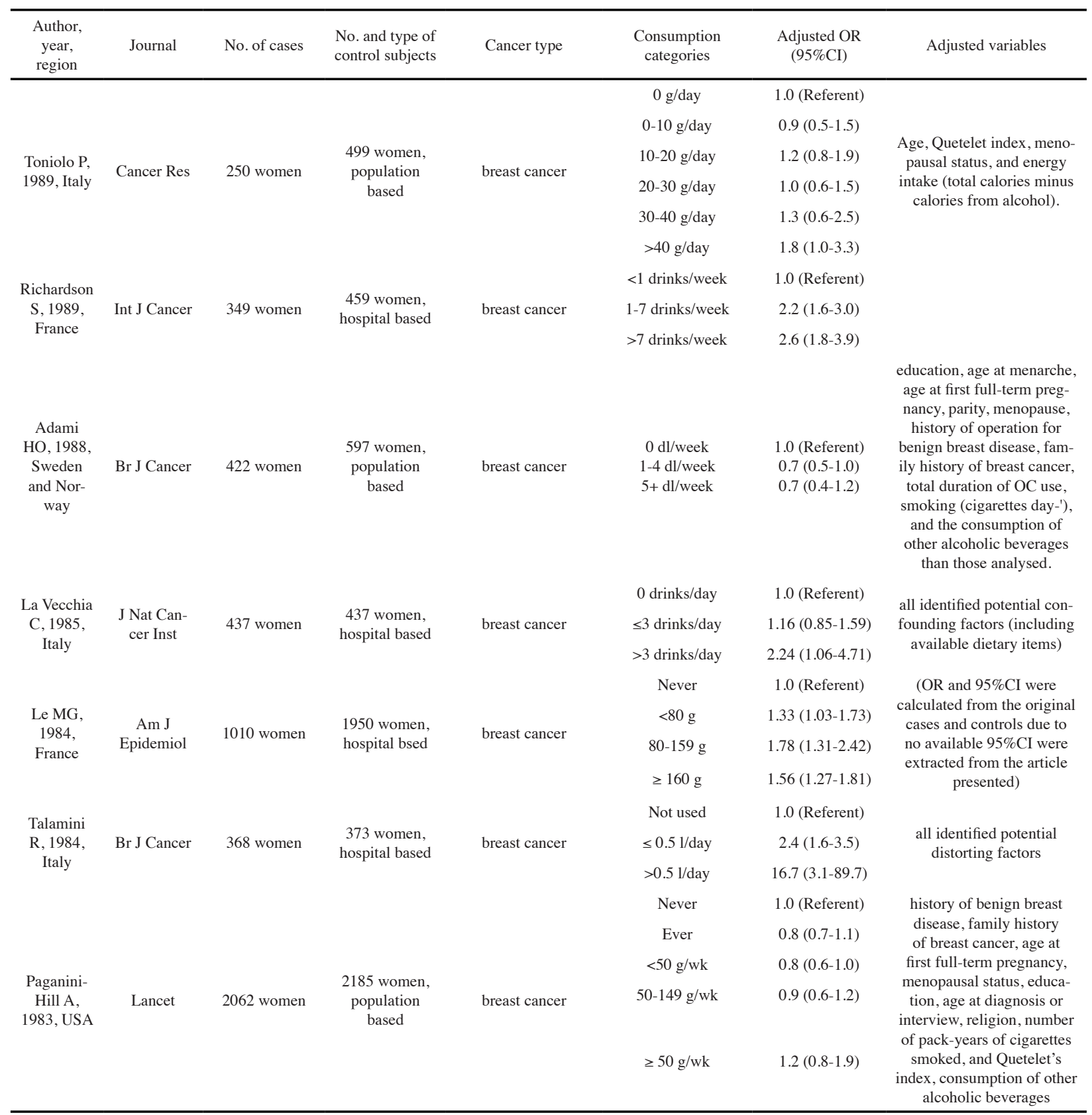

${ }^{\mathrm{a}} \mathrm{OR}=$ odds ratio; $\mathrm{CI}=$ confidence interval; $\mathrm{BMI}=$ body mass index; $\mathrm{BRAC}=; \mathrm{T}=$ tertile; $\mathrm{BRCA}=$ breast cancer susceptibility gene; $\mathrm{b}$ intake from wine was 0.0 of resveratrol for the 1 st tertile, ranged between 0.1 and 176.8 for the $2^{\text {nd }}$ tertile, $>176.8$ for the $3^{\text {rd }}$ tertile;

\section{Discussion}

To our knowledge, our meta-analysis, for the first time, evaluated the dose-response relationship between exposure to wine and risk of breast cancer. Our comprehensive metaanalysis indicated that wine consumption may increase the risk of breast cancer. However, when evaluating women drinking wine in different dosages, we found that a low dose may have some protective effect rather than an increased risk in heavy drinkers.

Consistent with many other studies, wine drinking is associated with increased risk of breast cancer risk in the highest versus lowest model. Wine, as a specific alcoholic drink, contains ethanol, which contribute to cancer risk in many published articles. The effects of ethanol may be mediated through the production of prostaglandins, lipid per-oxdation, and the generation of free radical oxygen species. Ethanol also acts as a solvent, enhancing penetration of carcinogens into cells (Wiseman, 2008). Interestingly, a recent study suggested that low dose of wine intake can decreased the risk of breast cancer (Bessaoud and Daures, 2008). In this study, the risk associated with women who consumed wine at low dose also showed decreased tendency at a non-linear dose-response model. The protective effect of low dose wine consumption on breast cancer is plausible for several reasons. First, wine contains high levels of anticancer compounds, such as polyphenols and resveratrol. A preclinical study tested the anti-proliferative activity of these compounds on the proliferation of different breast cancer cell lines, showing that low concentrations (nanomolar or even the picomolar range) of these active 
Table 3. Methodological Quality of Cohort Studies Included in the Meta-analysis

\begin{tabular}{|c|c|c|c|c|c|c|c|c|c|c|}
\hline $\begin{array}{l}\text { Author, year, } \\
\text { region }\end{array}$ & $\begin{array}{c}\text { Representativeness } \\
\text { of the exposed } \\
\text { cohort }\end{array}$ & $\begin{array}{l}\text { Selection } \\
\text { of the } \\
\text { unexposed } \\
\text { cohort }\end{array}$ & $\begin{array}{l}\text { Ascertainment } \\
\text { of exposure }\end{array}$ & $\begin{array}{l}\text { Outcome } \\
\text { of interest } \\
\text { not } \\
\text { present } \\
\text { at start of } \\
\text { study }\end{array}$ & $\begin{array}{l}\text { Control for } \\
\text { important } \\
\text { factor or } \\
\text { additional } \\
\text { factors b }\end{array}$ & $\begin{array}{l}\text { Outcome } \\
\text { assessment }\end{array}$ & $\begin{array}{l}\text { Follow- } \\
\text { up long } \\
\text { enough } \\
\text { for } \\
\text { outcomes } \\
\text { to occur c }\end{array}$ & $\begin{array}{l}\text { Adequacy } \\
\text { of follow- } \\
\text { up of } \\
\text { cohorts d }\end{array}$ & $\begin{array}{c}\text { Data } \\
\text { analysis } \\
\text { that used } \\
\text { an energy- } \\
\text { adjusted } \\
\text { residual or } \\
\text { nutrient- } \\
\text { density } \\
\text { model }\end{array}$ & $\begin{array}{c}\text { Total } \\
\text { quality } \\
\text { scores }\end{array}$ \\
\hline $\begin{array}{c}\text { Link LB, 2013, } \\
\text { USA }\end{array}$ & - & $\grave{厶}$ & 次 & 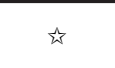 & 地施 & $\dot{x}$ & 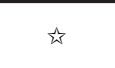 & $\hbar$ & 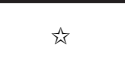 & 9 \\
\hline $\begin{array}{l}\text { Kabat GC, } \\
\text { 2011, USA }\end{array}$ & - & 牙 & 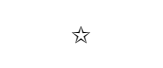 & $\Delta$ & 论㑔 & 弐 & 头 & $\vec{\omega}$ & - & 8 \\
\hline $\begin{array}{l}\text { Mattission I, } \\
\text { 2004, Sweden }\end{array}$ & - & $\sqrt{t}$ & 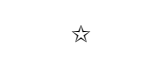 & 烄。 & 放数 & 次 & 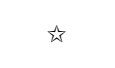 & 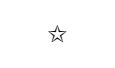 & $\Delta$ & 9 \\
\hline $\begin{array}{l}\text { Petri AL, 2004, } \\
\text { Denmark }\end{array}$ & $\Delta$ & 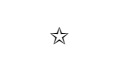 & $\widehat{x}$ & 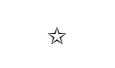 & 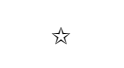 & 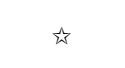 & 必 & 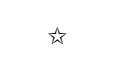 & - & 9 \\
\hline $\begin{array}{c}\text { Horn-Ros PL, } \\
\text { 2002, USA }\end{array}$ & - & 幽 & 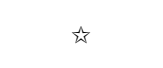 & 弐 & 故㑔 & 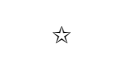 & - & 讼 & 弐 & 8 \\
\hline $\begin{array}{c}\text { Zhang Y, 2000, } \\
\text { USA }\end{array}$ & 必 & $\star \Delta$ & $\widehat{x}$ & 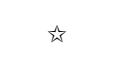 & 谈㑔 & 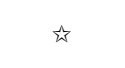 & 必 & - & - & 8 \\
\hline $\begin{array}{l}\text { Hiatt RA, } \\
\text { 1988, USA }\end{array}$ & 弐 & $\lesssim$ & $\dot{x}$ & 弐 & 论坛 & 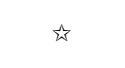 & - & - & - & 7 \\
\hline $\begin{array}{l}\text { Willett WC, } \\
\text { 1987, USA }\end{array}$ & - & $\grave{\lambda}$ & 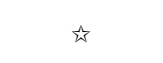 & $\Delta$ & 头 & 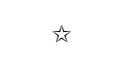 & - & 次 & $\Delta$ & 8 \\
\hline
\end{tabular}

${ }^{\mathrm{a}}$ A study could be awarded a maximum of one star for each item except for the item Control for important factor or additional factor; ${ }^{\mathrm{b}}$ A maximum of 2 stars could be awarded for this item. Studies that controlled for smoking and alcohol received one star, whereas studies that controlled for other important confounders such as family history or somking received an additional star; ${ }^{\mathrm{c}}$ A cohort study with a follow-up time $>8 \mathrm{y}$ was assigned one star; ${ }^{\mathrm{d}} \mathrm{A}$ cohort study with a follow-up rate $>75 \%$ was assigned one star

substances obtained after moderate wine ingestion might have a protective effect against breast cancer(Damianaki et al., 2000). In vitro experiments, polyphenols found in grapes showed the activity to induce cancer cells apoptosis and delay tumor growth (Castillo-Pichardo et al., 2009). In the animal model, transgenic mice also demonstrated decreased incidence rates of cancers with red wine solid food ingestion (Clifford et al., 1996). Secondly, some studies explored other mechanism pathways in which wine may serve as a kind of nutritional aromatase inhibitors (AI) (Byrne et al., 2002). The results showed that sex hormone binding globulin (SHBG) and luteinizing hormone (LH) were higher in serum with red wine consumption, which was explained by the hypothalamic up-regulation in response to lower estrogen levels. Thus, wine may not increase breast cancer risk via the hormonal shift patterns. Thirdly, a previous cohort study suggested that wine consumption induce breast density inversion in postmenopausal women after adjusting for other sources of alcohol (Boyd et al., 2006). Some epidemiologic studies have confirmed that breast density was risk factor for breast cancer(Flom et al., 2009). Other possible mechanisms of action need to be investigated in future.

In subgroup analysis by study design, case-control studies, especially hospital-based case-control studies, seemed to report much higher relative risks than cohort studies. The inconsistent findings may have been attributed to greater recall and selection biases in case-control studies because of their retrospective nature. And most non-high-quality studies are case-control ones, which further explain these results. When compared the RRs in different regions, we observed great difference in RR across geographic area. The RRs in European countries, especially France and Italy, were higher than that of USA and Canada. This may be due to the distinctions of diet patterns among different geographic regions. In many European countries, wine is usually an integral part of the resident's dietary habits daily diet.

Strengths of our studies include a large size (18106 breast cancer cases from 8 cohort studies and 18 case-control studies) and a quantitative dose-response analysis. Also, results from high-quality, cohort studies and studies adjusted for a variety of confounders are relatively consistent. Nevertheless, several limitations in our meta-analysis need to be mentioned. First of all, we noted that the majority of the cases were extracted from case-control studies, which are generally based on the memory and past record leading to more recall bias than cohort studies. Secondly, all the studies included only covered the Whites, lacking the diversity of races. Thirdly, as food-frequency questionnaires were used in each component studies, our findings were likely to be influenced by the underestimation of wine consumption. Besides, the potential misclassification of wine ingestion dose also may affect our results due to the broad range of definition of conversion in wine consumption.

Considering drinking is associated with increased risk of other health problems in women, such as birth defects, stroke, and other many types of cancers(Wiseman, 2008). Because wine consumption has increased in the general population, especially among young women, further research to clarify the relative safety in women is needed.

In conclusion, our analysis indicates that high dose of wine drinking is associated with increased risk of breast cancer, while low dose reduce the risk. However, future well-designed cohort or interventional studies are needed to confirm the findings and elucidate the underlying mechanisms. 


\begin{tabular}{|c|c|c|c|c|c|c|c|c|c|c|}
\hline $\begin{array}{l}\text { First author, } \\
\text { year }\end{array}$ & $\begin{array}{c}\text { Adequate } \\
\text { definition } \\
\text { of cases }\end{array}$ & $\begin{array}{l}\text { Representativeness } \\
\text { of cases }\end{array}$ & $\begin{array}{c}\text { Selection } \\
\text { of control } \\
\text { subjects }\end{array}$ & $\begin{array}{c}\text { Definition } \\
\text { of control } \\
\text { subjects }\end{array}$ & $\begin{array}{l}\text { Control } \\
\text { for } \\
\text { important } \\
\text { factor or } \\
\text { additional } \\
\text { factors }^{\mathrm{b}}\end{array}$ & $\begin{array}{c}\text { Exposure } \\
\text { assessment }\end{array}$ & $\begin{array}{c}\text { Same } \\
\text { method of } \\
\text { ascertainment } \\
\text { for all subjects }\end{array}$ & $\begin{array}{l}\text { Nonresponse } \\
\text { rate }^{\mathrm{c}}\end{array}$ & $\begin{array}{c}\text { Data } \\
\text { analysis } \\
\text { that used } \\
\text { an energy- } \\
\text { adjusted } \\
\text { residual or } \\
\text { nutrient- } \\
\text { density } \\
\text { model }\end{array}$ & $\begin{array}{l}\text { Total } \\
\text { quality } \\
\text { scores }\end{array}$ \\
\hline $\begin{array}{l}\text { Dennis J, } \\
\text { 2010, Eight } \\
\text { countries } \\
\text { of Europe } \\
\text { and North } \\
\text { America }\end{array}$ & - & tै & - & th & 败放 & - & है & - & - & 5 \\
\hline $\begin{array}{c}\text { Bissonauth } \\
\text { V, 2009, } \\
\text { Canada }\end{array}$ & है & th & tक & « & - & tर & है & - & th & 7 \\
\hline $\begin{array}{l}\text { Levi F, 2005, } \\
\text { Switzerland, }\end{array}$ & - & 经 & - & s th & - & « & और & - & - & 4 \\
\hline $\begin{array}{c}\text { Lenz SK, } \\
2002, \\
\text { Canada }\end{array}$ & $\star \Delta$ & th & - & $\vec{\omega}$ & 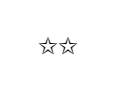 & 访 & th & $\widehat{\omega}$ & - & 8 \\
\hline $\begin{array}{c}\text { Ferraroni M, } \\
\text { 1998, Italy }\end{array}$ & - & 论 & - & 勾 & 谈场 & $\vec{\omega}$ & th & 论 & th & 8 \\
\hline $\begin{array}{l}\text { Viel JF, } \\
\text { 1997, France }\end{array}$ & - & th & है & $\widehat{t}$ & 该败 & - & $\widehat{\omega} \pi$ & $\widehat{\omega}$ & th & 8 \\
\hline $\begin{array}{l}\text { Levi F, 1996, } \\
\text { Switzerland }\end{array}$ & $\widehat{k}$ & th & - & $\widehat{t}$ & 论教 & $\vec{\omega}$ & $\vec{\omega}$ & $\widehat{\omega}$ & - & 8 \\
\hline $\begin{array}{l}\text { Freudenheim } \\
\text { JL, 1995, } \\
\text { USA }\end{array}$ & $\hbar$ & 勾 & th & - & 该败 & $\hat{\omega}$ & है & $\widehat{\omega}$ & th & 9 \\
\hline $\begin{array}{l}\text { Martin- } \\
\text { Moreno JM, } \\
\text { 1993, Spain }\end{array}$ & 勾 & 胫 & 访 & $\vec{k}$ & 放弥 & 访 & 㑱 & 访 & $\vec{t}$ & 10 \\
\hline $\begin{array}{l}\text { Ferraroni M, } \\
\text { 1991, Italy }\end{array}$ & - & th & - & 勾 & $\vec{\omega}$ & th & $\widehat{\omega}$ & - & th & 6 \\
\hline $\begin{array}{c}\text { Rosenberg } \\
\text { L, 1990, } \\
\text { Canada }\end{array}$ & - & th & $\Delta$ it & - & 论坛 & tर & $\widehat{\omega}$ & th & - & 7 \\
\hline $\begin{array}{l}\text { Toniolo P, } \\
\text { 1989, Italy }\end{array}$ & $\widehat{k}$ & th & $\vec{t}$ & - & 数教 & - & $\vec{\omega}$ & th & $\vec{t}$ & 8 \\
\hline $\begin{array}{c}\text { Richardson } \\
\text { S, 1989, } \\
\text { France }\end{array}$ & - & 勾 & - & 放 & $\vec{\omega}$ & - & th & 论 & - & 5 \\
\hline $\begin{array}{c}\text { Adami } \\
\text { HO, 1988, } \\
\text { Sweden and } \\
\text { Norway }\end{array}$ & $\widehat{k}$ & $\hat{\omega}$ & th & $\widehat{t}$ & 许话 & th & th & 放 & - & 9 \\
\hline $\begin{array}{c}\text { La Vecchia } \\
\text { C, } 1985 \\
\text { Italy }\end{array}$ & - & th & - & th & $\hat{k}$ & - & th & th & th & 6 \\
\hline $\begin{array}{l}\text { Talamini R, } \\
\text { 1984, Italy }\end{array}$ & - & 勾 & - & 放 & 论放 & - & th & 论 & - & 6 \\
\hline $\begin{array}{l}\text { Lê MG, } \\
\text { 1984, France }\end{array}$ & - & th & - & $\overrightarrow{k T}$ & 败弥 & - & $\vec{\omega}$ & 访 & - & 6 \\
\hline $\begin{array}{c}\text { Paganini- } \\
\text { Hill A, 1983, } \\
\text { USA }\end{array}$ & - & th & 数 & - & 论数 & - & $\vec{k}$ & th & - & 6 \\
\hline
\end{tabular}

a A study could be awarded a maximum of one star for each item except for the item Control for important factor or additional factor.

${ }^{\mathrm{b}}$ A maximum of 2 stars could be awarded for this item. Studies that controlled for smoking and alcohol received one star, whereas studies that controlled for other important confounders such as family history or fresh vegetables and fruit intake received an additional star.

${ }^{\mathrm{c}}$ One star was assigned if there was no significant difference in the response rate between control subjects and cases by using the chi-square test $(\mathrm{P}>0.05)$

\section{Acknowledgements}

This work was supported the Natural Science Foundation of China (No. 81272504), Innovation Team
[No. LJ201123 (EH11)], Jiangsu Provincial Science and Technology Projects [BK2011854 (DA11)], “333” Project of Jiangsu Province [BRA2012210 (RS12)], A Project Funded by the Priority Academic Program Development of Jiangsu Higher Education Institutions 
DOI:http://dx.doi.org/10.7314/APJCP.2016.17.3.1221

Dose-Dependent Association Between Wine Drinking and Breast Cancer Risk

Table 5. Summary Relative Risks (RRs) of the Association between wine Drinking and Breast Cancer Risk ${ }^{\mathrm{a}}$

\begin{tabular}{|c|c|c|c|c|c|c|}
\hline & \multirow{2}{*}{ No. of studies } & \multirow{2}{*}{ No. of cases } & \multirow{2}{*}{$\mathrm{RR}(95 \% \mathrm{CI})$} & \multicolumn{3}{|c|}{ Test of heterogeneity } \\
\hline & & & & Q & $P$ & $\mathrm{I}^{2} \%$ \\
\hline Overall studies & 26 & 21149 & $1.36(1.20-1.54)$ & 75.69 & $<0.001$ & 67.0 \\
\hline High-quality studies (score $\geq 7$ ) & 18 & 15650 & $1.26(1.12-1.43)$ & 38.89 & 0.002 & 56.3 \\
\hline \multicolumn{7}{|l|}{ Study design } \\
\hline Cohort studies & 8 & 9531 & $1.25(1.07-1.46)$ & 14.94 & 0.037 & 53.1 \\
\hline Case-control studies & 18 & 11618 & $1.44(1.19-1.73)$ & 54.61 & $<0.001$ & 68.9 \\
\hline Population-based controls & 9 & 5515 & $1.14(0.85-1.53)$ & 20.47 & 0.009 & 60.9 \\
\hline Hospital-based controls & 9 & 6103 & $1.72(1.38-2.15)$ & 23.77 & 0.003 & 66.3 \\
\hline \multicolumn{7}{|l|}{ Menopause } \\
\hline Premenopausal & 3 & 2062 & $1.79(1.34-2.40)$ & 2.13 & 0.344 & 6.3 \\
\hline Postmenopausal & 5 & 7396 & $1.20(0.94-1.53)$ & 10.96 & 0.027 & 63.5 \\
\hline \multicolumn{7}{|l|}{ Geographic region } \\
\hline Europe & 14 & 7950 & $1.66(1.35-2.05)$ & 39.05 & $<0.001$ & 66.7 \\
\hline Italy & 5 & 3839 & $1.89(1.17-3.07)$ & 13.09 & 0.011 & 69.4 \\
\hline France & 3 & 1513 & $2.12(1.37-3.27)$ & 7.49 & 0.024 & 73.3 \\
\hline North America & 11 & 12510 & $1.18(1.09-1.27)$ & 17.98 & 0.055 & 44.4 \\
\hline USA & 8 & 11518 & $1.16(1.01-1.35)$ & 14.59 & 0.042 & 52.0 \\
\hline Canada & 3 & 992 & $1.34(1.10-1.64)$ & 1.39 & 0.498 & 0.0 \\
\hline \multicolumn{7}{|l|}{ Adjustments } \\
\hline Family history & 13 & 15991 & $1.29(1.10-1.52)$ & 35.66 & $<0.001$ & 66.3 \\
\hline BMI & 16 & 17237 & $1.26(1.09-1.45)$ & 35.67 & 0.002 & 58.0 \\
\hline Total energy & 10 & 8009 & $1.50(1.15-1.94)$ & 31.15 & $<0.001$ & 71.1 \\
\hline Other alcoholic beverage & 9 & 5396 & $1.24(0.93-1.67)$ & 25.94 & 0.001 & 69.2 \\
\hline Smoking & 12 & 8553 & $1.30(1.02-1.65)$ & 32.36 & 0.001 & 66.0 \\
\hline Menopause & 16 & 15126 & 1.35 (1.14-1.59) & 42.15 & $<0.001$ & 64.4 \\
\hline Hormone therapy & 10 & 10328 & $1.26(1.01-1.56)$ & 26.63 & 0.002 & 66.2 \\
\hline Pregnancy & 15 & 16620 & $1.29(1.11-1.51)$ & 41.87 & $<0.001$ & 66.6 \\
\hline Education & 12 & 8652 & $1.36(1.10-1.67)$ & 29.02 & 0.002 & 62.1 \\
\hline Physical activity & 8 & 9142 & $1.38(1.06-1.79)$ & 24.46 & 0.001 & 71.4 \\
\hline
\end{tabular}

${ }^{\mathrm{a}} \mathrm{RR}=$ relative risk (odds ratio); $\mathrm{CI}$ = confidence interval; $\mathrm{BMI}=$ body mass index

(PAPD) (JX10231801), and grants from Key Academic

Discipline of Jiangsu Province "Medical Aspects of

Specific Environments".

\section{References}

Adami HO, Lund E, Bergstrom R, et al (1988). Cigarette smoking, alcohol consumption and risk of breast cancer in young women. Br J Cancer, 58, 832-7.

Arveux $P$, Bertaut A (2013). Epidemiology of breast cancer. Rev Prat, 63, 1362-6.

Bessaoud F, Daures JP (2008). Patterns of alcohol (especially wine) consumption and breast cancer risk: a case-control study among a population in Southern France. Ann Epidemiol, 18, 467-75.

Bissonauth V, Shatenstein B, Fafard E, et al (2009). Risk of breast cancer among French-Canadian women, noncarriers of more frequent BRCA1/2 mutations and consumption of total energy, coffee, and alcohol. Breast J, 15 Suppl 1, S63-71.

Boyd NF, Martin LJ, Li Q, et al (2006). Mammographic density as a surrogate marker for the effects of hormone therapy on risk of breast cancer. Cancer Epidemiol Biomarkers Prev, 15, 961-6.

Byrne C, Webb PM, Jacobs TW, et al (2002). Alcohol consumption and incidence of benign breast disease. Cancer Epidemiol Biomarkers Prev, 11, 1369-74.

Castillo-Pichardo L, Martinez-Montemayor MM, Martinez JE, et al (2009). Inhibition of mammary tumor growth and metastases to bone and liver by dietary grape polyphenols. Clin Exp Metastasis, 26, 505-16.

Chen WY, Rosner B, Hankinson SE, et al (2011). Moderate alcohol consumption during adult life, drinking patterns, and breast cancer risk. JAMA, 306, 1884-90.

Clifford AJ, Ebeler SE, Ebeler JD, et al (1996). Delayed tumor onset in transgenic mice fed an amino acid-based diet supplemented with red wine solids. Am J Clin Nutr, 64, 748-56.

Corrao G, Bagnardi V, Zambon A, et al (1999). Exploring the dose-response relationship between alcohol consumption and the risk of several alcohol-related conditions: a metaanalysis. Addiction, 94, 1551-73.

Damianaki A, Bakogeorgou E, Kampa M, et al (2000). Potent inhibitory action of red wine polyphenols on human breast cancer cells. J Cell Biochem, 78, 429-41.

Dennis J, Ghadirian $P$, Little J, et al (2010). Alcohol consumption and the risk of breast cancer among BRCA1 and BRCA2 mutation carriers. Breast, 19, 479-83.

Egger M, Davey Smith G, Schneider M, et al (1997). Bias in meta-analysis detected by a simple, graphical test. BMJ, 315, 629-34.

Ellison RC, Zhang Y, McLennan CE, et al (2001). Exploring the relation of alcohol consumption to risk of breast cancer. Am $J$ Epidemiol, 154, 740-7.

Eng ET, Ye J, Williams D, et al (2003). Suppression of estrogen biosynthesis by procyanidin dimers in red wine and grape seeds. Cancer Res, 63, 8516-22.

Espie M, Lalloum M, Coussy F (2013). Epidemiology and risk factors of breast cancer. Soins, 22-4.

Ferraroni M, Decarli A, Franceschi S, et al (1998). Alcohol 
Table 6. Slope of Each Study and Relative Risks

\begin{tabular}{|c|c|c|c|c|c|}
\hline study & B & $\mathrm{Se}(\mathrm{B})$ & RR & LB & UB \\
\hline Adami HO 1988 Sweden and & -0.06803 & 0.03849 & 0.93423 & 0.86634 & 1.00745 \\
\hline Dennis J 20101 & -0.11580 & 0.00060 & 0.89065 & 0.88960 & 0.89170 \\
\hline Dennis J 20102 & 0.00858 & 0.01081 & 1.00862 & 0.98747 & 1.03022 \\
\hline Ferraroni M 1991 Italy & 0.01830 & 0.01034 & 1.01847 & 0.99804 & 1.03933 \\
\hline Freudenheim JL 1995 USA1 & -0.01523 & 0.01380 & 0.98489 & 0.95861 & 1.01188 \\
\hline Freudenheim JL 1995 USA2 & -0.01152 & 0.01510 & 0.98854 & 0.95971 & 1.01824 \\
\hline Freudenheim JL 1995 USA3 & -0.01613 & 0.01776 & 0.98400 & 0.95033 & 1.01887 \\
\hline Freudenheim JL 1995 USA4 & -0.02766 & 0.05681 & 0.97272 & 0.87023 & 1.08728 \\
\hline Horn-Ros PL 2002 USA & 0.02306 & 0.00635 & 1.02333 & 1.01068 & 1.03614 \\
\hline Levi F 1996 Switzerland & 0.02391 & 0.00772 & 1.02419 & 1.00881 & 1.03982 \\
\hline Lê MG 1984 France & 0.01624 & 0.00321 & 1.01637 & 1.01001 & 1.02278 \\
\hline Martin-Moreno JM 1993 Sp & 0.03065 & 0.00858 & 1.03113 & 1.01393 & 1.04862 \\
\hline Paganini-Hill A 1983 USA & 0.00657 & 0.00740 & 1.00659 & 0.99209 & 1.02129 \\
\hline Petri AL 2004 Denmark1 & 0.01934 & 0.02693 & 1.01953 & 0.96711 & 1.07479 \\
\hline Petri AL 2004 Denmark2 & 0.01968 & 0.01614 & 1.01988 & 0.98812 & 1.05266 \\
\hline Petri AL 2004 Denmark3 & -0.00840 & 0.02359 & 0.99164 & 0.94683 & 1.03856 \\
\hline Richardson S 1989 France & 0.07206 & 0.01251 & 1.07472 & 1.04869 & 1.10139 \\
\hline Rosenberg L 1990 Canada & -0.00231 & 0.02481 & 0.99770 & 0.95034 & 1.04741 \\
\hline Talamini R 1984 Italy & 0.04674 & 0.00923 & 1.04785 & 1.02906 & 1.06697 \\
\hline Viel JF 1997 France1 & 0.09981 & 0.03298 & 1.10496 & 1.03579 & 1.17874 \\
\hline Viel JF 1997 France2 & 0.03227 & 0.18599 & 1.03280 & 0.71730 & 1.48707 \\
\hline Willett WC 1987 USA & 0.05560 & 0.01849 & 1.05717 & 1.01955 & 1.09618 \\
\hline Zhang Y 2000 USA1 & -0.00053 & 0.03012 & 0.99947 & 0.94216 & 1.06026 \\
\hline Zhang Y 2000 USA2 & -0.07375 & 0.05822 & 0.92890 & 0.82873 & 1.04118 \\
\hline
\end{tabular}

Table 7. Does-response Analysis ${ }^{\mathrm{a}}$ in Linear Model

\begin{tabular}{lccccccc}
\hline \multirow{2}{*}{ Model } & Pooled E (SE) & RR/OR(CI) & Z-score & $\begin{array}{c}\text { Linear } \\
\text { Treand }\end{array}$ & & Test for hererogeneity & \\
\cline { 3 - 7 } & & & & p-value & p-value & Q \\
\hline Fixed & $-0.1053(0.0006)$ & $0.9001(0.8991,0.9011)$ & -182.19 & 0 & $<0.0001$ & 89.13 \\
Random & $0.0059(0.0201)$ & $1.0059(0.9670,1.0464)$ & 0.2939 & 0.7688 & & \\
\hline
\end{tabular}

${ }^{a}$ Greenland method for test of non-linearity: $\chi^{2}=1763.9 \mathrm{P}<0.0001$

consumption and risk of breast cancer: a multicentre Italian case-control study. Eur J Cancer, 34, 1403-9.

Ferraroni M, Decarli A, Willett WC, et al (1991). Alcohol and breast cancer risk: a case-control study from northern Italy. Int J Epidemiol, 20, 859-64.

Flom JD, Ferris JS, Tehranifar $P$, et al (2009). Alcohol intake over the life course and mammographic density. Breast Cancer Res Treat, 117, 643-51.

Freudenheim JL, Marshall JR, Graham S, et al (1995). Lifetime alcohol consumption and risk of breast cancer. Nutr Cancer, 23, 1-11.

Hamajima N, Hirose K, Tajima K, et al (2002). Alcohol, tobacco and breast cancer--collaborative reanalysis of individual data from 53 epidemiological studies, including 58,515 women with breast cancer and 95,067 women without the disease. Br J Cancer, 87, 1234-45.

Hiatt RA, Klatsky AL, Armstrong MA (1988). Alcohol consumption and the risk of breast cancer in a prepaid health plan. Cancer Res, 48, 2284-7.

Higgins JP, Thompson SG, Deeks JJ, et al (2003). Measuring inconsistency in meta-analyses. BMJ, 327, 557-60.

Horn-Ross PL, Hoggatt KJ, West DW, et al (2002). Recent diet and breast cancer risk: the California Teachers Study (USA). Cancer Causes Control, 13, 407-15.

Kabat GC, Kim M, Phipps AI, et al (2011). Smoking and alcohol consumption in relation to risk of triple-negative breast cancer in a cohort of postmenopausal women. Cancer Causes
Control, 22, 775-83.

Key J, Hodgson S, Omar RZ, et al (2006). Meta-analysis of studies of alcohol and breast cancer with consideration of the methodological issues. Cancer Causes Control, 17, 759-70.

La Vecchia C, Decarli A, Franceschi S, et al (1985). Alcohol consumption and the risk of breast cancer in women. J Natl Cancer Inst, 75, 61-5.

Le MG, Hill C, Kramar A, et al (1984). Alcoholic beverage consumption and breast cancer in a French case-control study. Am J Epidemiol, 120, 350-7.

Lenz SK, Goldberg MS, Labreche F, et al (2002). Association between alcohol consumption and postmenopausal breast cancer: results of a case-control study in Montreal, Quebec, Canada. Cancer Causes Control, 13, 701-10.

Levi F, Pasche C, Lucchini F, et al (2005). Resveratrol and breast cancer risk. Eur J Cancer Prev, 14, 139-42.

Levi F, Pasche C, Lucchini F, et al (1996). Alcohol and breast cancer in the Swiss Canton of Vaud. Eur J Cancer, 32, 2108-13.

Link LB, Canchola AJ, Bernstein L, et al (2013). Dietary patterns and breast cancer risk in the California Teachers Study cohort. Am J Clin Nutr, 98, 1524-32.

Martin-Moreno JM, Boyle $P$, Gorgojo L, et al (1993). Alcoholic beverage consumption and risk of breast cancer in Spain. Cancer Causes Control, 4, 345-53.

Mattisson I, Wirfalt E, Wallstrom $P$, et al (2004). High fat and alcohol intakes are risk factors of postmenopausal breast 
cancer: a prospective study from the Malmo diet and cancer cohort. Int J Cancer, 110, 589-97.

Petri AL, Tjonneland A, Gamborg M, et al (2004). Alcohol intake, type of beverage, and risk of breast cancer in pre- and postmenopausal women. Alcohol Clin Exp Res, 28, 1084-90.

Richardson S, de Vincenzi I, Pujol H, et al (1989). Alcohol consumption in a case-control study of breast cancer in southern France. Int J Cancer, 44, 84-9.

Rosenberg L, Palmer JR, Miller DR, et al (1990). A case-control study of alcoholic beverage consumption and breast cancer. Am J Epidemiol, 131, 6-14.

Seitz HK, Stickel F (2007). Molecular mechanisms of alcoholmediated carcinogenesis. Nat Rev Cancer, 7, 599-612.

Singletary KW, Gapstur SM (2001). Alcohol and breast cancer: review of epidemiologic and experimental evidence and potential mechanisms. JAMA, 286, 2143-51.

Smith-Warner SA, Spiegelman D, Yaun SS, et al (1998). Alcohol and breast cancer in women: a pooled analysis of cohort studies. JAMA, 279, 535-40.

Talamini R, La Vecchia C, Decarli A, et al (1984). Social factors, diet and breast cancer in a northern Italian population. $\mathrm{Br} J$ Cancer, 49, 723-9.

Toniolo $P$, Riboli E, Protta F, et al (1989). Breast cancer and alcohol consumption: a case-control study in northern Italy. Cancer Res, 49, 5203-6.

Viel JF, Perarnau JM, Challier B, et al (1997). Alcoholic calories, red wine consumption and breast cancer among premenopausal women. Eur J Epidemiol, 13, 639-43.

Webster LA, Layde PM, Wingo PA, et al (1983). Alcohol consumption and risk of breast cancer. Lancet, 2, 724-6.

Willett WC, Howe GR, Kushi LH (1997). Adjustment for total energy intake in epidemiologic studies. Am J Clin Nutr, 65, 1220-8.

Willett WC, Stampfer MJ, Colditz GA, et al (1987). Moderate alcohol consumption and the risk of breast cancer. $N$ Engl J Med, 316, 1174-80.

Wiseman M (2008). The second World Cancer Research Fund/ American Institute for Cancer Research expert report. Food, nutrition, physical activity, and the prevention of cancer: a global perspective. Proc Nutr Soc, 67, 253-6.

Zhang Y, Kreger BE, Dorgan JF, et al (1999). Alcohol consumption and risk of breast cancer: the Framingham Study revisited. Am J Epidemiol, 149, 93-101. 